\title{
Role of Synucleins in Alzheimer's Disease
}

\author{
Leslie Crews · Igor Tsigelny $\cdot$ Makoto Hashimoto • \\ Eliezer Masliah
}

Received: 22 April 2009/Revised: 7 May 2009/Accepted: 8 June 2009/Published online: 24 June 2009

(C) The Author(s) 2009. This article is published with open access at Springerlink.com

\begin{abstract}
Alzheimer's disease (AD) and Parkinson's disease (PD) are the most common causes of dementia and movement disorders in the elderly. While progressive accumulation of oligomeric amyloid- $\beta$ protein $(\mathrm{A} \beta)$ has been identified as one of the central toxic events in $\mathrm{AD}$ leading to synaptic dysfunction, accumulation of $\alpha$-synuclein ( $\alpha$-syn) resulting in the formation of oligomers has been linked to PD. Most of the studies in AD have been focused on investigating the role of $\mathrm{A} \beta$ and Tau; however, recent studies suggest that $\alpha$-syn might also play a role in the pathogenesis of AD. For example, fragments of $\alpha$-syn can associate with amyloid plaques and $\mathrm{A} \beta$ promotes the aggregation of $\alpha$-syn in vivo and worsens the deficits in $\alpha$-syn tg mice. Moreover, $\alpha$-syn has also been shown to accumulate in limbic regions in $\mathrm{AD}$, Down's syndrome, and familial AD cases. A $\beta$ and $\alpha$-syn might directly interact under pathological conditions leading
\end{abstract}

L. Crews · E. Masliah ( $\square)$

Department of Neurosciences, University of California

San Diego, La Jolla, CA 92093-0624, USA

e-mail: emasliah@UCSD.edu

L. Crews · E. Masliah

Department of Pathology, University of California

San Diego, La Jolla, CA 92093-0624, USA

I. Tsigelny

Department of Chemistry and Biochemistry, University of California San Diego, La Jolla, CA 92093-0624, USA

\section{Tsigelny}

San Diego Super Computer Center, University of California San Diego, La Jolla, CA 92093-0624, USA

\section{Hashimoto}

Laboratory for Chemistry and Metabolism, Tokyo Metropolitan Institute for Neuroscience, Fuchu, Tokyo, Japan to the formation of toxic oligomers and nanopores that increase intracellular calcium. The interactions between $\mathrm{A} \beta$ and $\alpha$-syn might also result in oxidative stress, lysosomal leakage, and mitochondrial dysfunction. Thus, better understanding the steps involved in the process of $\mathrm{A} \beta$ and $\alpha$-syn aggregation is important in order to develop intervention strategies that might prevent or reverse the accumulation of toxic proteins in AD.

Keywords Synuclein · Alzheimer's · Parkinson's · Amyloid · APP
Abbreviations
$\mathrm{AD} \quad$ Alzheimer's disease
A $\beta \quad$ Amyloid- $\beta$ protein
$\alpha$-syn $\alpha$-Synuclein
PD Parkinson's disease

\section{Introduction to the Pathogenesis of $\mathrm{AD}$}

Alzheimer's disease (AD) and Parkinson's disease (PD) are the most common causes of dementia and movement disorders in the elderly. While progressive accumulation of amyloid- $\beta$ protein $(\mathrm{A} \beta)$ oligomers has been identified as one of the central toxic events in AD leading to synaptic dysfunction (Klein et al. 2001; Walsh and Selkoe 2004; Glabe 2005), accumulation of $\alpha$-synuclein ( $\alpha$-syn) resulting in the formation of oligomers has been linked to PD (Giasson et al. 2000; Lee et al. 2001; Lashuel et al. 2002; Hashimoto et al. 2003b; Tsigelny et al. 2007). Alzheimer's disease and PD overlap in a heterogeneous group of disorders denominated Lewy body disease (LBD) (McKeith et al. 2005) where both $A \beta$ and $\alpha$-syn accumulate in the brain. Several lines of evidence now support a role for 
$\alpha$-syn not only in PD but also in additional disorders including AD, multiple system atrophy (MSA), and others (Trojanowski et al. 1998).

Alzheimer's disease continues to be the leading cause of dementia in the aging population (Ashford 2004). Over 5 million people live with this devastating neurological condition and it is estimated that the US will experience an average $50 \%$ increase in patients with AD by the year 2025 (Hebert et al. 2004). Alzheimer's disease is a progressive neurodegenerative disorder that specifically damages limbic structures, the association neocortical pathways (Hof and Morrison 1991; Masliah et al. 1993; Braak and Braak 1994; Hof and Morrison 1994), and the cholinergic system (Perry et al. 1978; Perry 1995). Although the key neuropathological diagnostic features of $\mathrm{AD}$ are the presence of plaques_composed of amyloid- $\beta$ (A $\beta$ ) peptides (Selkoe 1990)_and tangles containing the microtubule binding protein Tau (Trojanowski et al. 1993), the neurodegenerative process in AD probably initiates with damage to the synaptic terminals (Scheff et al. 1990; Terry et al. 1991; Masliah and Terry 1994). It has been postulated that the early synaptic pathology leads to axonal abnormalities (Goldstein et al. 2003), spine (Spires et al. 2005) and dendritic atrophy (Moolman et al. 2004), and eventually neuronal loss (Terry et al. 1991; Mucke et al. 2000). Therefore, disruption of the mechanisms involved in modulating synaptic plasticity might be responsible for the characteristic cognitive deficits in $\mathrm{AD}$ patients and as such represent an important target for treatment development.

Although the precise mechanisms leading to neurodegeneration in $\mathrm{AD}$ are not completely understood, several lines of investigation indicate that alterations in the amyloid precursor protein (APP), resulting in the accumulation of amyloid- $\beta$ protein $(\mathrm{A} \beta)$ and APP $\mathrm{C}$-terminal products, might play a key role in the pathogenesis of AD (Selkoe 1994a, b; Sisodia and Price 1995; Sinha et al. 2000; Kamenetz et al. 2003) (Fig. 1). Several products are derived from APP through alternative proteolytic cleavage pathways, and enormous progress has recently been made in identifying the enzymes involved (Selkoe 1999; Sinha

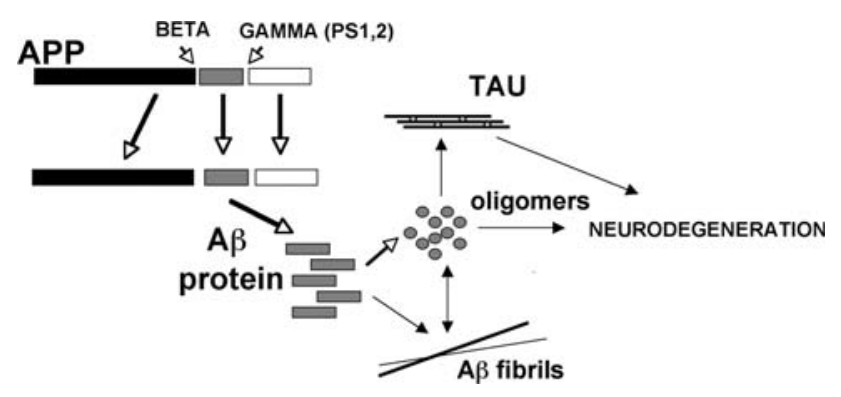

Fig. 1 Schematic representation of the metabolism of APP and the formation of $\mathrm{A} \beta$ aggregates et al. 1999; Vassar et al. 1999; Cai et al. 2001; Luo et al. 2001).

While most research has been centered at investigating the role of $\mathrm{APP} / \mathrm{A} \beta$ and Tau in the pathogenesis of $\mathrm{AD}$, however, recent studies suggest that $\alpha$-syn might also play a role in the pathogenesis of this neurodegenerative disorder (Iwai et al. 1995a; Iwai 2000) (Fig. 2).

\section{The Synuclein Family of Proteins in Health and Disease}

$\alpha$-Synuclein is an abundant presynaptic molecule (Iwai et al. 1995b) that plays a role in modulating vesicular synaptic release (Murphy et al. 2000). Synucleins belong to a family of related proteins including $\alpha-, \beta$-, and $\gamma$-syn. $\alpha$-Synuclein belongs to a class of so-called naturally unfolded proteins (Lansbury 1999; Wright and Dyson 1999) (Fig. 3). $\alpha$-Synuclein contains a highly amyloidogenic hydrophobic domain in the N-terminus region (aa 60-95) (Fig. 3) which is partially absent in $\beta$-syn and might explain why $\beta$-syn has a reduced ability to selfaggregate and form oligomers and fibrils (Hashimoto et al. 2001; Uversky et al. 2002). Moreover, previous studies have shown that $\beta$-syn interacts with $\alpha$-syn and is capable of preventing $\alpha$-syn aggregation and related deficits both in vitro and in vivo (Hashimoto et al. 2001). Overall, synucleins are believed to be involved in regulation of synaptic plasticity and dopamine neurotransmitter release (Murphy et al. 2000).

$\alpha$-Synuclein plays a role in synaptic adaptations, including synaptic plasticity during development, learning (Clayton and George 1998), and regulation of synaptic vesicle mobilization at nerve terminals (Cabin et al. 2002). Additionally, previous studies have shown that $\alpha$-syn may have important non-synaptic physiological functions that occur through interactions with other molecules such as the scaffolding protein Sept4 (Ihara et al. 2007) and the synaptic vesicle protein cysteine-strong protein- $\alpha$ (CSP $\alpha)$

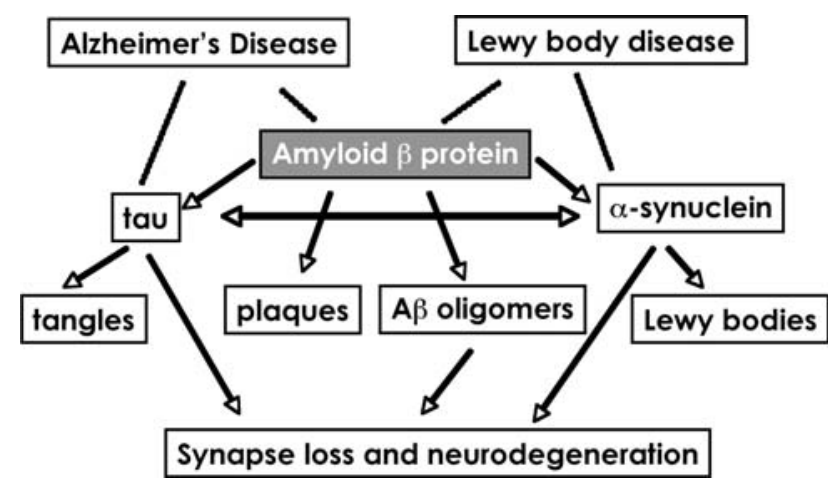

Fig. 2 Role of the interactions between $\mathrm{A} \beta, \alpha$-syn, and Tau in the pathogenesis of $\mathrm{AD}$ and $\mathrm{LBD}$ 
Fig. 3 Molecular dynamics of $\alpha$-syn structure and progressive aggregation leading to the formation of toxic oligomers

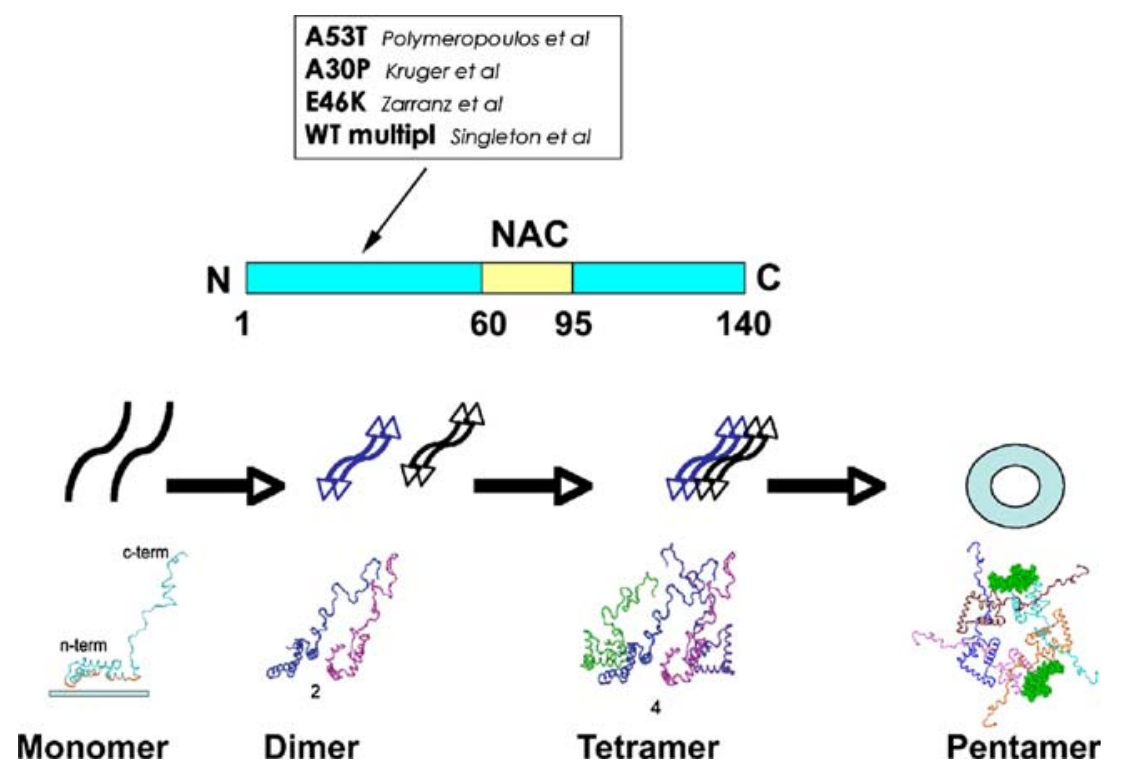

(Chandra et al. 2005). $\alpha$-Synuclein has been implicated in the pathogenesis not only of LBD (Trojanowski et al. 1998; Hashimoto and Masliah 1999) but also of other disorders with parkinsonism, including MSA (Spillantini et al. 1998; Wakabayashi et al. 1998b; Wakabayashi et al. 1998a). These disorders are collectively referred to as synucleinopathies (Hardy and Gwinn-Hardy 1998) and might share common pathogenic pathways that promote toxic conversion of $\alpha$-syn.

Various lines of evidence support the contention that abnormal aggregates arise from a partially folded intermediate precursor that contains hydrophobic patches. It has been proposed that the intermediate $\alpha$-syn oligomers form annular protofibrils and pore-like structures (Ding et al. 2002; Volles and Lansbury 2002; Lashuel et al. 2003; Rochet et al. 2004; Tsigelny et al. 2007) (Fig. 3). The mechanisms through which monomeric $\alpha$-syn converts into a toxic oligomer and later into fibrils is currently under intense investigation. Recent studies suggest that $\alpha$-syn oligomerization might occur on the membrane and involves interactions between hydrophobic residues of the amphipathic $\alpha$-helices of $\alpha$-syn (Zhu et al. 2003). These studies indicate that the hydrophobic lipid-binding domains in the N-terminal region might be important in modulating $\alpha$-syn aggregation (Conway et al. 1998; Lansbury 1999; Uversky et al. 2001; Jao et al. 2004).

Molecular modeling and molecular dynamic simulations showed that $\alpha$-syn homodimers could adopt non-propagating (head-to-tail) and propagating (head-to-head) conformations (Tsigelny et al. 2007) (Fig. 3). Propagating $\alpha$-syn dimers on the membrane incorporate additional $\alpha$-syn molecules, leading to the formation of pentamers and hexamers, which form rings suggestive of pore-like structures (Tsigelny et al. 2007) (Fig. 3). Oligomers form complexes in the membranes of neurons that facilitate abnormal calcium currents that might disturb synaptic and neuronal function leading to neurodegeneration (Danzer et al. 2007).

In conclusion, it is likely that $\alpha$-syn oligomers might be responsible for the neurodegenerative process in LBD/PD. The Lewy bodies (LBs), which primarily contain $\alpha$-syn fibrils, might represent a cellular mechanism to isolate more toxic oligomers. The $\alpha$-syn oligomers most likely associate with the neuronal membranes and synapses, interfering with neurotransmission and plasticity. Thus, better understanding the steps involved in the process of $\alpha$-syn aggregation is important in order to develop intervention strategies that might prevent or reverse $\alpha$-syn oligomerization and toxic conversion.

\section{Disease Models, Knockouts, Assays}

\section{APP tg Animal Models of AD}

The main focus of the following sections in $\mathrm{AD}$ will be on models involving amyloid deposition and Tau hyperphosphorylation. In $\mathrm{AD}$, mutations in PS1 and 2 and polymorphisms in apolipoprotein $\mathrm{E}$ (ApoE) have been also linked with AD and as such are important targets. Recently developed tg animal models have shown that it is possible to reproduce certain aspects of AD pathology over a shorter period of time (Masliah et al. 1996b; Games et al. 1997; Price et al. 2000). In one such model, the platelet-derived growth factor ( $\beta$ chain) (PDGF- $\beta$ ) promoter drives an alternatively spliced human APP (hAPP) minigene (PDAPP) encoding mutated $\mathrm{V} \rightarrow \mathrm{F}$ hAPP695, 751, 770 (Games et al. 1995; Rockenstein et al. 1995). This confers 
a high ratio of mRNA encoding mutated hAPP versus wt mouse APP (Rockenstein et al. 1995) that promotes development of typical amyloid plaques, dystrophic neurites, loss of presynaptic terminals, astrocytosis, and microgliosis (Games et al. 1995; Masliah et al. 1996b; Games et al. 1997).

Other models have expressed mutant hAPP under the regulatory control of either the human or murine (m)Thy-1 promoter (Andra et al. 1996; Sturchler-Pierrat et al. 1997; Moechars et al. 1999; Bornemann and Staufenbiel 2000) or the protease-resistant prion protein ( $\mathrm{PrP}$ ) promoter (Hsiao et al. 1996; Borchelt et al. 1997). Amyloid deposition begins at 12 months of age; however, co-expression of mutant PS1 accelerates amyloid deposition, beginning at 4 months of age (Borchelt et al. 1996; Borchelt et al. 1997; Holcomb et al. 1998). Another more recently developed model, where APP is also expressed under the control of the PrP promoter, displays even earlier onset of amyloid deposition, starting at 3 months and progressing to mature plaques and neuritic pathology from 5 months of age, accompanied by high levels of $\mathrm{A} \beta_{1-42}$ (Chishti et al. 2001). While the PrP promoter has provided several models that mimic aspects of familial AD (FAD), other promoters targeting expression of APP to neurons provide alternative models demonstrating pathology that recapitulate similar and additional aspects of FAD. In this regard, we have generated lines of $\mathrm{tg}$ mice expressing hAPP751 cDNA containing the London (V717I) and Swedish (K670M/ N671L) mutations under the regulatory control of the murine (m)Thy-1 gene (mThy1-hAPP751) (Rockenstein et al. 2001). Therefore, while expression of mutant hAPP under the PDGF- $\beta$ promoter results in the production of diffuse (and some mature) plaques (Games et al. 1995; Mucke et al. 2000), tg expression of mutant hAPP under the mThy-1 (Andra et al. 1996) and PrP (Hsiao et al. 1996; Borchelt et al. 1997) promoters favors the formation of mature plaques in the hippocampus and neocortex. This suggests that the differential patterns of $\mathrm{A} \beta$ deposition might be dependent on the specific neuronal populations selected by the promoter, levels of expression and topographical distribution of the transgene, and levels of $\mathrm{A} \beta_{1-40}$ and $\mathrm{A} \beta_{1-42}$. Consistent with this, in FAD and Down syndrome, production of high levels of $\mathrm{A} \beta_{1-42}$ results in early plaque formation (Citron et al. 1997). This suggests that early age of onset and plaque formation depends on high levels of $\mathrm{A} \beta_{1-42}$ production (Rockenstein et al. 2001).

More recent models have been focused toward modeling the role of $\mathrm{A} \beta$ protofibril generation and other mutations in APP in the pathogenesis of AD. Of them, the most interesting are those expressing APP bearing the Arctic mutation. These mice rapidly develop extensive plaque formation (Cheng et al. 2004). For a review of these and additional tg models of neurodegenerative disease, please visit the Alzheimer's Forum website at: http://www.alz forum.org/res/com/tra.

$\alpha$-Synuclein Transgenic Models of PD and LBD

Since progressive intraneuronal aggregation of $\alpha$-syn has been proposed to play a central role in the pathogenesis of PD and related disorders (Hashimoto and Masliah 1999; Trojanowski and Lee 2000; Volles and Lansbury 2002), most $\mathrm{tg}$ models have been focused at investigating the in vivo effects of $\alpha$-syn accumulation utilizing neuron-specific promoters. Several recent reviews have been published addressing this subject (Hashimoto et al. 2003a; Fernagut and Chesselet 2004). Among these models, overexpression of wt $\alpha$-syn under the regulatory control of the PDGF- $\beta$ promoter has been shown to result in motor deficits, dopaminergic loss, and formation of inclusion bodies (Masliah et al. 2000). Mice with the highest levels of expression (line D) showed intraneuronal accumulation of $\alpha$-syn that started at 3 months of age and was accompanied by the loss of tyrosine hydroxylase (TH) fibers in the caudoputamen region and synapses in the temporal cortex. Although no apparent neuronal loss was detected in the substantia nigra (SN), measurements of dopamine levels in the caudoputamen region showed a 25-50\% reduction at 12 months of age. Consistent with these results, $\operatorname{tg}$ mice showed mild to moderate motor deficits in the rotarod, particularly in mice with the greatest loss of dopamine, indicating that more substantial deficits $(>75 \%)$ of this transmitter might be necessary for more overt deficits to appear. In mThy-1-hasyn tg mice, this protein accumulated in synapses and neurons throughout the brain, including the thalamus, basal ganglia, $\mathrm{SN}$, and brainstem (Rockenstein et al. 2002; Fleming et al. 2004).

Because previous studies have shown that mutations associated with familial parkinsonism accelerate $\alpha$-syn aggregation and oligomerization (Conway et al. 1998; Narhi et al. 1999), we compared the patterns of neurodegeneration, $\alpha$-syn aggregation, and neurological alterations in $\operatorname{tg}$ mice expressing wt or mutant (A53T) h $\alpha$-syn at comparable levels under the PDGF- $\beta$ promoter. Remarkably, we found that mice expressing low levels of mutant h $\alpha$-syn developed progressive motor deficits and neurodegeneration associated with $h \alpha$-syn accumulation in synapses and neurons, but very few or no inclusions were found (Hashimoto et al. 2003a). Similarly, mice expressing high levels of mutant A53T, but not wt or A30P mutant, $\alpha$-syn developed a severe and complex motor impairment leading to paralysis and death (Giasson et al. 2002; Lee et al. 2002; von Coelln et al. 2006). In contrast to our model expressing low levels of mutant $\alpha$-syn, animals expressing higher levels of A53T $\alpha$-syn developed agedependent intracytoplasmic neuronal $\alpha$-syn inclusions 
paralleling disease onset, and the $\alpha$-syn inclusions recapitulated features of human disorders. Moreover, immunoelectron microscopy revealed that the $\alpha$-syn inclusions contained $10-16 \mathrm{~nm}$ wide fibrils similar to human pathological inclusions. These mice demonstrate that A53T $\alpha$-syn leads to the formation of toxic filamentous $\alpha$-syn neuronal inclusions that cause neurodegeneration (Giasson et al. 2002).

This spectrum of $\alpha$-syn-associated neurodegenerative phenotypes in various tg models can be partially attributed to the different effects conferred by expressing mutant versus wt $\alpha$-syn. Another important factor is the promoters selected to drive $\alpha$-syn expression, which regulate both expression levels and cell-type specificity. For example, under the mThy-1 promoter, expression of either wt or mutant $\alpha$-syn (van der Putten et al. 2000) results in extensive insoluble $\alpha$-syn accumulation throughout the CNS including, in some cases, in the $\mathrm{SN}$ or motor neurons (Rockenstein et al. 2002). Under the mouse PrP promoter, expression of mutant A53T $\alpha$-syn enhanced the accumulation of aggregation-promoting C-terminally truncated species of $\alpha$-syn (Li et al. 2005). Under the rat TH promoter, expression of double mutant $h \alpha$-syn adversely affects the integrity of dopaminergic terminals and leads to age-related declines in motor coordination and dopaminergic markers (Richfield et al. 2002).

Further studies to investigate the role of $\alpha$-syn mutations and selective neuronal vulnerability in the SN have been performed in rats utilizing lentiviral and adeno-associatedviral vectors (Kirik et al. 2002; Klein et al. 2002; Lo Bianco et al. 2002). In contrast to tg mice models, a selective loss of nigral dopaminergic neurons associated with a dopaminergic denervation of the striatum was observed in animals expressing either wt or mutant forms of $h \alpha$-syn. This neuronal degeneration correlates with the appearance of abundant $\alpha$-syn-positive inclusions and extensive neuritic pathology detected with both $\alpha$-syn and silver staining. Rat $\alpha$-syn similarly leads to protein aggregation but without cell loss, suggesting that inclusions are not the primary cause of cell degeneration in PD (Lo Bianco et al. 2002).

In summary, these in vivo models support the contention that $\alpha$-syn-dependent neurodegeneration is associated with abnormal accumulation of detergent-insoluble $\alpha$-syn (probably representing oligomeric forms) rather than with inclusion formation representing fibrillar polymeric $\alpha$-syn. The specific accumulation of detergent-insoluble $\alpha$-syn in these $\operatorname{tg}$ mice recapitulates a pivotal feature of LBD (Kahle et al. 2001) and it is of significant importance in the future development and evaluation of novel treatments.

\section{Disease Targets and Ligands for Combined AD and PD}

\section{$\alpha$-Synuclein as a Target in Combined AD/PD}

$\alpha$-Synuclein was originally identified in $\mathrm{AD}$ plaques as the precursor protein of the non- $\mathrm{A} \beta$ component (NAC) of $\mathrm{AD}$ amyloid (Fig. 4a) and thus was called non-amyloid component of plaques (NACP) (Ueda et al. 1993; Iwai et al. 1995a; Masliah et al. 1996a; Iwai 2000). NAC, a highly hydrophobic 35 -amino acid domain within the $\alpha$-syn molecule, may be involved in amyloid formation (Iwai et al. 1995a) (Fig. 3). NAC is highly amyloidogenic and aggregates to form fibrils under oxidative conditions (Hashimoto et al. 1997; Hashimoto et al. 1999), and NAC also interacts with $\mathrm{A} \beta$ and promotes $\mathrm{A} \beta$ aggregation (Yoshimoto et al. 1995).

Remarkably, several studies have now confirmed that the pathology of $\mathrm{AD}$ and $\mathrm{PD}$ overlap in a heterogeneous group of conditions denominated jointly LBD (McKeith 2000; Lippa et al. 2007). Approximately $25 \%$ of all cases of AD develop parkinsonism and about $50 \%$ of all cases of PD develop AD-type dementia after 65 years of age (Hansen et al. 1990). Moreover, $70 \%$ of patients with
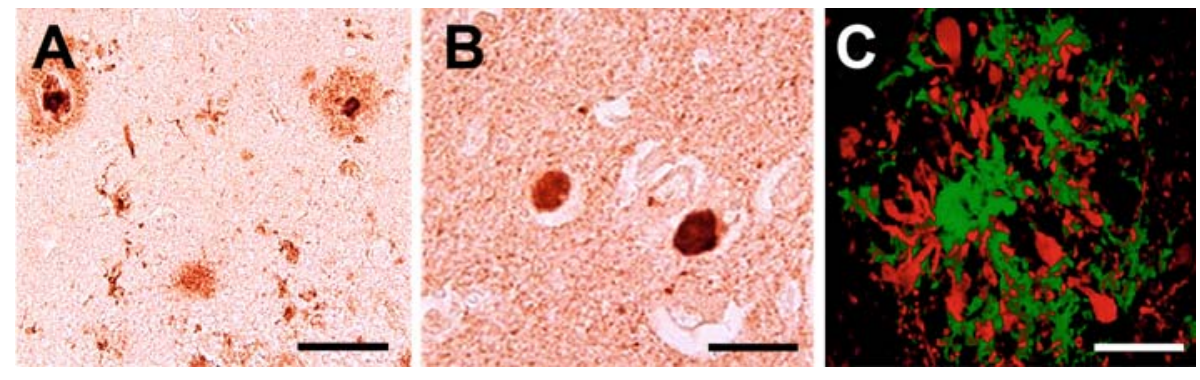

Fig. 4 Characteristics of $\alpha$-syn aggregates and inclusions in the brains of $\mathrm{AD}$ patients. a Representative section from the brain of an $\mathrm{AD}$ patient immunostained with an antibody against the NAC region of $\alpha$-syn. The staining shows characteristic plaques composed of $\mathrm{A} \beta$ protein. b Representative section from the brain of an AD patient immunostained with an antibody against $\alpha$-syn that detected Lewy body-like inclusions in the neocortex. $\mathbf{c}$ Representative section from the brain of an AD patient double immunolabeled with antibodies against $\mathrm{A} \beta$ and $\alpha$-syn shows co-localization of the two signals in plaques. Scale bar, $20 \mu \mathrm{m}(\mathbf{a}), 10 \mu \mathrm{m}(\mathbf{b}, \mathbf{c})$ 
sporadic $\mathrm{AD}$ display the formation of $\alpha$-syn-positive LB-like inclusions in the amygdala and limbic structures (Lippa et al. 1998; Trojanowski et al. 1998; Hamilton 2000 ) and by the time of autopsy, approximately $90 \%$ of patients with probable LBD also meet the Reagan pathologic criteria for AD (Hyman and Trojanowski 1997; McKeith et al. 2005). Similarly, in patients with FAD and Down's syndrome, LB-like pathology and parkinsonism have been reported (Lippa et al. 1999). Interestingly, the brains of patients with DLB and PDD display very similar pathology, with the exception that recent studies have shown extensive deposition of $\mathrm{A} \beta$ and $\alpha$-syn in the striatum and hippocampus in DLB compared to only $\alpha$-syn in PDD cases (Duda et al. 2002; Jellinger and Attems 2006). Furthermore, previous studies provide extensive support for an interaction between pathogenic pathways in $\mathrm{AD}$ and $\mathrm{PD}$, in particular FAD cases with presenilin mutations that present with significant LB pathology (Rosenberg 2005; Snider et al. 2005; Leverenz et al. 2006). The amyloidogenic fragment, NAC, of $\alpha$-syn is found in the amyloid plaque (Hashimoto et al. 2000) (Fig. 4a), although some controversy has emerged in this respect (Culvenor et al. 1999). The dystrophic neurites in the plaques from AD patients display intense $\alpha$-syn immunoreactivity (Masliah et al. 1996a) (Fig. 4), $\alpha$-syn-positive aggregates are found in limbic regions in AD (Lippa et al. 1999) (Fig. 4b) and the overall levels of $\alpha$-syn are abnormal in the early stages of AD (Iwai et al. 1996). Moreover, genetic polymorphisms in the $\alpha$-syn gene have been shown to regulate the susceptibility to AD (Xia et al. 1996; Tsigelny et al. 2008).

Underlying interactions between $\alpha$-syn and $\mathrm{A} \beta$ play a fundamental role in the pathogenesis of LBD (Lippa et al. 1998; Hashimoto et al. 2000; Masliah et al. 2001; Pletnikova et al. 2005). Specifically, $\mathrm{A} \beta$ worsens the deficits associated with $\alpha$-syn accumulation (Pettegrew 1989; Lippa et al. 1998; Lippa et al. 2005; Pletnikova et al. 2005; Deramecourt et al. 2006; Mandal et al. 2006; Lippa et al. 2007), and $\mathrm{A} \beta$ promotes the oligomerization and toxic conversion of $\alpha$-syn (Masliah et al. 2001; Mandal et al. 2006) (Fig. 5), suggesting that $\mathrm{A} \beta$ and $\alpha$-syn might directly interact in vitro and in vivo. In support of this possibility, under pathological conditions, both aggregated $\mathrm{A} \beta$ and $\alpha$-syn might associate with membranes and accumulate in caveolae (Soto et al. 1994; Bouillot et al. 1996; Eliezer et al. 2001; Fortin et al. 2004; Kubo et al. 2005; Bar-On et al. 2006; Kim et al. 2006; Bar-On et al. 2008; Williamson et al. 2008). Consistent with these findings, our recent studies have shown that $\mathrm{A} \beta$ and $\alpha$-syn co-localize in membrane and caveolar fractions, and $\mathrm{A} \beta$ stabilizes $\alpha$-syn multimers that might form channel-like structures in the membrane (Tsigelny et al. 2008). Moreover, lipid rafts in the membrane have been postulated to play a role in oligomerization of misfolded proteins (Soto et al. 1994; Kazlauskaite and Pinheiro 2005; Kim et al. 2006) including $\alpha$-syn (Fortin et al. 2004; Bar-On et al. 2006; Bar-On et al. 2008) and A $\beta$ (Soto et al. 1994; Kim et al. 2006; Williamson et al. 2008) and might represent a suitable site for the abnormal interactions between aggregated forms of $\alpha$-syn and $\mathrm{A} \beta$. Furthermore, highly amyloidogenic intraneuronal A $\beta$ (Wilson et al. 1999) has been shown to accumulate in the endoplasmic reticulum (Cook et al. 1997; Hartmann et al. 1997), Golgi apparatus (Xu et al. 1997; Xia et al. 2000), and the endosome-lysosome system (Koo and Squazzo 1994), and these organelles may provide additional sites for interaction between $\mathrm{A} \beta$ and $\alpha$-syn. In support of this possibility, aggregated forms of $\mathrm{A} \beta$ and $\alpha$-syn have been independently described in several intracellular membranous structures (Bahr and Bendiske 2002; Hashimoto et al. 2003b; Lee et al. 2005; Nixon and Cataldo 2006); (Tsigelny et al. 2007).

\section{Mechanisms of Neurodegeneration and Interactions Between $\alpha$-syn and $\mathrm{A} \beta$ in Combined $\mathrm{AD} / \mathrm{PD}$}

The aggregates of $\alpha$-syn might independently contribute to the neurodegenerative process in $\mathrm{AD}$ or via interactions with $\mathrm{A} \beta$. Most studies have investigated the formation of toxic oligomeric species derived from homologous monomers. We have recently investigated the interactions between heterogeneous proteins that can form toxic hybrid oligomers, showing that $\mathrm{A} \beta$ and $\alpha$-syn can interact in vivo and in vitro (Tsigelny et al. 2008). Supporting these findings, $\mathrm{A} \beta$ and $\alpha$-syn co-immunoprecipitated in the brains of patients with LBD as well as in double APP/ $\alpha$-syn transgenic (tg) mice. Furthermore, molecular modeling studies showed that these interactions promoted the formation of
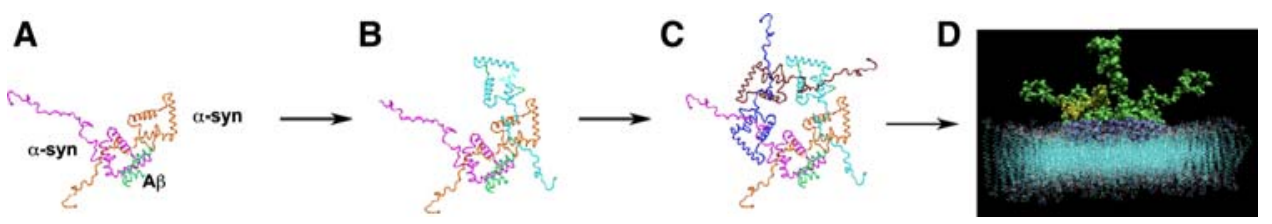

Fig. 5 Molecular dynamics of $\alpha$-syn and $\mathrm{A} \beta$ interactions leading to the formation of hybrid pores in the membrane. a Conformation of $\alpha$-syn dimer in the presence of one molecule of $\mathrm{A} \beta$. $\mathbf{b}$ Conformation of $\alpha$-syn trimer with the $\mathrm{A} \beta$ monomer. c Conformation of $\alpha$-syn

pentamer with the $\mathrm{A} \beta$ monomer and the formation of a central porelike channel. d Space-filled model showing the pore-like $\alpha$-syn pentamer with the $\mathrm{A} \beta$ monomer embedded in a membrane 
highly stable ring-like oligomers composed of both $\mathrm{A} \beta$ and $\alpha$-syn and these species dock in the membrane (Fig. 5). Similarly, in vitro studies confirmed that both freshly solubilized as well as aggregated $\mathrm{A} \beta$ and $\alpha$-syn can directly interact and form hybrid ring-like structures.

In agreement with this possibility, a previous study showed that $\mathrm{A} \beta$ promotes the aggregation of $\alpha$-syn in vivo and worsens the deficits in $\alpha$-syn tg mice (Masliah et al. 2001). Moreover, $\alpha$-syn has also been shown to accumulate in the brains of APP tg (Yang et al. 2000) and APP/ presenilin-1 (PS1) double tg mice that produce large amounts of $\mathrm{A} \beta$ (Kurata et al. 2007). In addition, as described in the previous section, several studies have now shown that in the brains of LBD patients, $\mathrm{A} \beta$ contributes to the levels and state of $\alpha$-syn aggregation and LB formation (Pettegrew 1989; Lippa et al. 1998; Lippa et al. 2005; Pletnikova et al. 2005; Deramecourt et al. 2006; Mandal et al. 2006; Lippa et al. 2007). Taken together, these studies in tg mice and human brains support the contention that $\mathrm{A} \beta$ and $\alpha$-syn interact in vivo and that these interactions are of significance in the pathogenesis of the disease.

A $\beta$ might promote $\alpha$-syn aggregation by directly interacting with $\alpha$-syn molecules bound to the membrane and therefore facilitating the formation of more stable oligomers. However, A $\beta$ might promote $\alpha$-syn aggregation through other pathways, including increased oxidative stress, calpain activation with C-terminal cleavage of $\alpha$-syn (Mishizen-Eberz et al. 2005; Dufty et al. 2007), and aberrant phosphorylation induced by secreted forms of $\mathrm{A} \beta$.

The hybrid multimers of $\mathrm{A} \beta$ and $\alpha$-syn might embed in the membrane (Fig. 5d) of mitochondria, lysosomes, and the plasma membrane, leading to the formation of nanopore-like structures resulting in abnormal ion conductance (Tsigelny et al. 2008). Previous studies have shown that A $\beta$ penetrates in the membrane and aggregates to form channels that facilitate the abnormal trafficking of cations such as $\mathrm{Ca}^{2+}$ and $\mathrm{K}^{+}$(Arispe et al. 1993; Arispe et al. 1996; Lin et al. 2001; Mattson 2007). Studies of $\alpha$-syn aggregation by atomic force microscopy have shown that the oligomers form heterogeneous pore-like structures that might induce cell death via disruption of calcium homeostasis (Quist et al. 2005; Danzer et al. 2007).

\section{Next Frontiers in Drug Discovery}

Alterations in the balance between factors promoting aggregation, clearance, and synthesis of $\mathrm{A} \beta$ and $\alpha$-syn might be centrally involved in the formation of oligomers and the pathogenesis of neurodegeneration. Clearance of A $\beta$ and $\alpha$-syn oligomers occurs primarily via degrading enzymes (neprilysin), chaperone molecules ( $\beta$-syn, HSP27, 70 ), and lysosomal pathways (autophagy). Immunotherapy approaches might reduce $\alpha$-syn accumulation by stimulating autophagy. Gene therapy approaches using viral vectors can be used to target these pathways involved in $\mathrm{A} \beta$ and $\alpha$-syn clearance. For example, delivery of neprilysin, an A $\beta$-degrading enzyme, into the brains of APP tg mice results in amelioration of the behavioral deficits, improved synaptic formation, and decreased $\mathrm{A} \beta$ accumulation. Since $\mathrm{A} \beta$ also promotes the aggregation of $\alpha$-syn, gene therapy delivery of neprilysin has also been shown to reduce the $\alpha$ syn pathology and deficits in tg mice expressing both APP and $\alpha$-syn. Another important clearance mechanism amenable for manipulation by gene therapy is the autophagy pathway. For this lysosomal degradation system, the oligomers are targeted to the chaperone-mediated system or to the macroautophagy pathway. In both $\mathrm{AD}$ and $\mathrm{PD}$ the autophagy pathway is abnormal. Therefore increasing autophagy with mTor antagonists and gene therapy to promote autophagy might be of therapeutical value. Such pro-clearance properties might also provide a novel strategy for the treatment of other neurodegenerative disorders.

\section{Conclusions}

In combined $\mathrm{AD} / \mathrm{PD}$, both $\mathrm{A} \beta$ and $\alpha$-syn might directly interact under pathological conditions leading to the formation of toxic oligomers and nanopores that increase intracellular calcium. Other mechanisms involved include oxidative stress, lysosomal leakage, and mitochondrial dysfunction. Thus, better understanding the steps involved in the process of $\mathrm{A} \beta$ and $\alpha$-syn aggregation is important in order to develop intervention strategies that might prevent or reverse the toxic conversion in $\mathrm{AD}$.

Acknowledgments This work was supported by NIH grants AG18440, AG022074, and AG10435, HL066012 and DOE INCITE grants. The authors are also grateful to IBM for funding under its Institutes of Innovation program and for computational support on its BlueGene computers at the San Diego Supercomputer Center and at the Argonne National Laboratory.

Open Access This article is distributed under the terms of the Creative Commons Attribution Noncommercial License which permits any noncommercial use, distribution, and reproduction in any medium, provided the original author(s) and source are credited.

\section{References}

Andra K, Abramowski D, Duke M, Probst A, Wiederholt K, Burki K, Goedert M, Sommer B, Staufenbiel M (1996) Expression of APP in transgenic mice: a comparison of neuron-specific promoters. Neurobiol Aging 17:183-190

Arispe N, Rojas E, Pollard HB (1993) Alzheimer disease amyloid beta protein forms calcium channels in bilayer membranes: blockade by tromethamine and aluminum. Proc Natl Acad Sci USA 90:567-571 
Arispe N, Pollard HB, Rojas E (1996) $\mathrm{Zn}^{2+}$ interaction with Alzheimer amyloid beta protein calcium channels. Proc Natl Acad Sci USA 93:1710-1715

Ashford JW (2004) APOE genotype effects on Alzheimer's disease onset and epidemiology. J Mol Neurosci 23:157-165

Bahr BA, Bendiske J (2002) The neuropathogenic contributions of lysosomal dysfunction. J Neurochem 83:481-489

Bar-On P, Rockenstein E, Adame A, Ho G, Hashimoto M, Masliah E (2006) Effects of the cholesterol-lowering compound methylbeta-cyclodextrin in models of alpha-synucleinopathy. J Neurochem 98:1032-1045

Bar-On P, Crews L, Koob AO, Mizuno H, Adame A, Spencer B, Masliah E (2008) Statins reduce neuronal alpha-synuclein aggregation in in vitro models of Parkinson's disease. J Neurochem 105:1656-1667

Borchelt D, Thinakaran G, Eckman C, Lee M, Davenport F, Ratovitsky T, Prada C, Kim G, Seekins S, Yager D (1996) Familial Alzheimer's disease-linked presenilin 1 variants elevate Ab1-42/1-40 ratio in vitro and in vivo. Neuron 17:1005-1013

Borchelt D, Ratovitski T, van Lare J, Lee M, Gonzales V, Jenkins N, Copeland N, Price D, Sisodia S (1997) Accelerated amyloid deposition in the brains of transgenic mice coexpressing mutamt presenilin 1 and amyloid precursor proteins. Neuron 19:939-945

Bornemann KD, Staufenbiel M (2000) Transgenic mouse models of Alzheimer's disease. Ann N Y Acad Sci 908:260-266

Bouillot C, Prochiantz A, Rougon G, Allinquant B (1996) Axonal amyloid precursor protein expressed by neurons in vitro is present in a membrane fraction with caveolae-like properties. J Biol Chem 271:7640-7644

Braak H, Braak E (1994) Morphological criteria for the recognition of Alzheimer's disease and the distribution pattern of cortical changes related to this disorder. Neurobiol Aging 15:355-356 discussion 379-380

Cabin DE, Shimazu K, Murphy D, Cole NB, Gottschalk W, McIlwain KL, Orrison B, Chen A, Ellis CE, Paylor R, Lu B, Nussbaum RL (2002) Synaptic vesicle depletion correlates with attenuated synaptic responses to prolonged repetitive stimulation in mice lacking alpha-synuclein. J Neurosci 22:8797-8807

Cai H, Wang Y, McCarthy D, Wen H, Borchelt DR, Price DL, Wong PC (2001) BACE1 is the major beta-secretase for generation of Abeta peptides by neurons. Nat Neurosci 4:233-234

Chandra S, Gallardo G, Fernandez-Chacon R, Schluter OM, Sudhof TC (2005) Alpha-synuclein cooperates with CSPalpha in preventing neurodegeneration. Cell 123:383-396

Cheng IH, Palop JJ, Esposito LA, Bien-Ly N, Yan F, Mucke L (2004) Aggressive amyloidosis in mice expressing human amyloid peptides with the Arctic mutation. Nat Med 10:1190-1192

Chishti MA, Yang DS, Janus C, Phinney AL, Horne P, Pearson J, Strome R, Zuker N, Loukides J, French J, Turner S, Lozza G, Grilli M, Kunicki S, Morissette C, Paquette J, Gervais F, Bergeron C, Fraser PE, Carlson GA, George-Hyslop PS, Westaway D (2001) Early-onset amyloid deposition and cognitive deficits in transgenic mice expressing a double mutant form of amyloid precursor protein 695. J Biol Chem 276:2156221570

Citron M, Westaway D, Xia W, Carlson G, Diehl T, Levesque G, Johnson-Wood K, Lee M, Subert P, Davis A, Kholodenko D, Motter R, Sherrington R, Perry B, Hong Y, Strome R, Lieberburg I, Rommens J, Kim S, Schenk D, Fraser P, St.George Hyslop P, Selkoe D (1997) Mutant presenilins of Alzheimer's disease increase production of 42-residue amyloid beta-protein in both transfected cells and transgenic mice. Nat Med 3:67-72

Clayton DF, George JM (1998) The synucleins: a family of proteins involved in synaptic function, plasticity, neurodegeneration and disease. Trends Neurosci 21:249-254
Conway KA, Harper JD, Lansbury PT (1998) Accelerated in vitro fibril formation by a mutant alpha-synuclein linked to earlyonset Parkinson disease. Nat Med 4:1318-1320

Cook DG, Forman MS, Sung JC, Leight S, Kolson DL, Iwatsubo T, Lee VM, Doms RW (1997) Alzheimer's A beta(1-42) is generated in the endoplasmic reticulum/intermediate compartment of NT2N cells. Nat Med 3:1021-1023

Culvenor JG, McLean CA, Cutt S, Campbell BC, Maher F, Jakala P, Hartmann T, Beyreuther K, Masters CL, Li QX (1999) NonAbeta component of Alzheimer's disease amyloid (NAC) revisited. NAC and alpha-synuclein are not associated with Abeta amyloid. Am J Pathol 155:1173-1181

Danzer KM, Haasen D, Karow AR, Moussaud S, Habeck M, Giese A, Kretzschmar H, Hengerer B, Kostka M (2007) Different species of alpha-synuclein oligomers induce calcium influx and seeding. J Neurosci 27:9220-9232

Deramecourt V, Bombois S, Maurage CA, Ghestem A, Drobecq H, Vanmechelen E, Lebert F, Pasquier F, Delacourte A (2006) Biochemical staging of synucleinopathy and amyloid deposition in dementia with Lewy bodies. J Neuropathol Exp Neurol 65:278-288

Ding TT, Lee SJ, Rochet JC, Lansbury PT Jr (2002) Annular alphasynuclein protofibrils are produced when spherical protofibrils are incubated in solution or bound to brain-derived membranes. Biochemistry 41:10209-10217

Duda JE, Giasson BI, Mabon ME, Lee VM, Trojanowski JQ (2002) Novel antibodies to synuclein show abundant striatal pathology in Lewy body diseases. Ann Neurol 52:205-210

Dufty BM, Warner LR, Hou ST, Jiang SX, Gomez-Isla T, Leenhouts KM, Oxford JT, Feany MB, Masliah E, Rohn TT (2007) Calpain-cleavage of \{alpha\}-synuclein: connecting proteolytic processing to disease-linked aggregation. Am J Pathol 170:1725-1738

Eliezer D, Kutluay E, Bussell R Jr, Browne G (2001) Conformational properties of alpha-synuclein in its free and lipid-associated states. J Mol Biol 307:1061-1073

Fernagut PO, Chesselet MF (2004) Alpha-synuclein and transgenic mouse models. Neurobiol Dis 17:123-130

Fleming SM, Salcedo J, Fernagut PO, Rockenstein E, Masliah E, Levine MS, Chesselet MF (2004) Early and progressive sensorimotor anomalies in mice overexpressing wild-type human alpha-synuclein. J Neurosci 24:9434-9440

Fortin DL, Troyer MD, Nakamura K, Kubo S, Anthony MD, Edwards RH (2004) Lipid rafts mediate the synaptic localization of alphasynuclein. J Neurosci 24:6715-6723

Games D, Adams D, Alessandrini R, Barbour R, Berthelette P, Blackwell C, Carr T, Clemes J, Donaldson T, Gillespie F, Guido T, Hagopian S, Johnson-Wood K, Khan K, Lee M, Leibowitz P, Lieberburg I, Little S, Masliah E, McConlogue L, MontoyaZavala M, Mucke L, Paganini L, Penniman E, Power M, Schenk D, Seubert P, Snyder B, Soriano F, Tan H, Vitale J, Wadsworth S, Wolozin B, Zhao J (1995) Alzheimer-type neuropathology in transgenic mice overexpressing $\mathrm{V} 717 \mathrm{~F}$ b-amyloid precursor protein. Nature 373:523-527

Games D, Masliah E, Lee M, Johnson-Wood K, Schenk D (1997) Neurodegenerative Alzheimer-like pathology in PDAPP $717 \mathrm{~V} \rightarrow \mathrm{F}$ transgenic mice. In: Hyman B, Duyckaerts $\mathrm{C}$, Christen Y (eds) Connections, cognition and Alzheimer's disease. Springer-Verlag, Berlin, pp 105-119

Giasson BI, Duda JE, Murray IV, Chen Q, Souza JM, Hurtig HI, Ischiropoulos H, Trojanowski JQ, Lee VM (2000) Oxidative damage linked to neurodegeneration by selective alpha-synuclein nitration in synucleinopathy lesions. Science 290:985-989

Giasson BI, Duda JE, Quinn SM, Zhang B, Trojanowski JQ, Lee VM (2002) Neuronal alpha-synucleinopathy with severe movement 
disorder in mice expressing A53T human alpha-synuclein. Neuron 34:521-533

Glabe CC (2005) Amyloid accumulation and pathogensis of Alzheimer's disease: significance of monomeric, oligomeric and fibrillar Abeta. Subcell Biochem 38:167-177

Goldstein L, Ashford JW, Busciglio J, Crutcher K, Gouras G, Kinoshita J, Mandelkow E, Sudol M (2003) Live discussion. From here to there: AbetaPP as an axonal transport receptor-how could this explain neurodegeneration in AD. 15 July 2002. J Alzheimers Dis 5:483-489

Hamilton RL (2000) Lewy bodies in Alzheimer's disease: a neuropathological review of 145 cases using alpha-synuclein immunohistochemistry. Brain Pathol 10:378-384

Hansen L, Salmon D, Galasko D, Masliah E, Katzman R, DeTeresa R, Thal L, Pay MM, Hofstetter R, Klauber M et al (1990) The Lewy body variant of Alzheimer's disease: a clinical and pathologic entity. Neurology 40:1-8

Hardy J, Gwinn-Hardy K (1998) Genetic classification of primary neurodegenerative disease. Science 282:1075-1079

Hartmann T, Bieger SC, Bruhl B, Tienari PJ, Ida N, Allsop D, Roberts GW, Masters CL, Dotti CG, Unsicker K, Beyreuther K (1997) Distinct sites of intracellular production for Alzheimer's disease A beta40/42 amyloid peptides. Nat Med 3:1016-1020

Hashimoto M, Masliah E (1999) Alpha-synuclein in Lewy body disease and Alzheimer's disease. Brain Pathol 9:707-720

Hashimoto M, Yoshimoto M, Sisk A, Hsu LJ, Sundsmo M, Kittel A, Saitoh T, Miller A, Masliah E (1997) NACP, a synaptic protein involved in Alzheimer's disease, is differentially regulated during megakaryocyte differentiation. Biochem Biophys Res Commun 237:611-616

Hashimoto M, Hsu LJ, Xia Y, Takeda A, Sisk A, Sundsmo M, Masliah E (1999) Oxidative stress induces amyloid-like aggregate formation of NACP/alpha-synuclein in vitro. Neuro Report 10:717-721

Hashimoto M, Takenouchi T, Mallory M, Masliah E, Takeda A (2000) The role of NAC in amyloidogenesis in Alzheimer's disease. Am J Pathol 156:734-736

Hashimoto M, Rockenstein E, Mante M, Mallory M, Masliah E (2001) b-Synuclein inhibits alpha-synuclein aggregation: a possible role as an anti-parkinsonian factor. Neuron 32:213-223

Hashimoto M, Rockenstein E, Masliah E (2003a) Transgenic models of alpha-synuclein pathology: past, present, and future. Ann N Y Acad Sci 991:171-188

Hashimoto M, Rockenstein E, Crews L, Masliah E (2003b) Role of protein aggregation in mitochondrial dysfunction and neurodegeneration in Alzheimer's and Parkinson's diseases. Neuromolecular Med 4:21-36

Hebert LE, Scherr PA, Bienias JL, Bennett DA, Evans DA (2004) State-specific projections through 2025 of Alzheimer disease prevalence. Neurology 62:1645

Hof PR, Morrison JH (1991) Neocortical neuronal subpopulations labeled by a monoclonal antibody to calbindin exhibit differential vulnerability in Alzheimer's disease. Exp Neurol 111:293301

Hof P, Morrison J (1994) The cellular basis of cortical disconnection in Alzheimer disease and related dementing conditions. In: Terry R, Katzman R, Bick K (eds) Alzheimer disease. Raven Press, New York, pp 197-230

Holcomb L, Gordon M, McGowan E, Yu X, Benkovic S, Jantzen P, Wright K, Saad I, Mueller R, Morgan D, Sanders P, Zehr C, O'Campo K, Hardy J, Prada C-M, Eckman C, Younkin S, Hsiao K, Duff K (1998) Accelerated Alzheimer-type phenotype in transgenic mice carrying both mutant amyloid precursor protein and presenilin 1 transgenes. Nat Med 4:97-100

Hsiao K, Chapman P, Nilsen S, Eckman C, Harigaya Y, Younkin S, Yang F, Cole G (1996) Correlative memory deficits, Ab elevation, and amyloid plaques in transgenic mice. Science 274:99-102

Hyman BT, Trojanowski JQ (1997) Consensus recommendations for the postmortem diagnosis of Alzheimer disease from the National Institute on Aging and the Reagan Institute Working Group on diagnostic criteria for the neuropathological assessment of Alzheimer disease. J Neuropathol Exp Neurol 56:1095-1097

Ihara M, Yamasaki N, Hagiwara A, Tanigaki A, Kitano A, Hikawa R, Tomimoto $\mathrm{H}$, Noda $\mathrm{M}$, Takanashi $\mathrm{M}$, Mori $\mathrm{H}$, Hattori $\mathrm{N}$, Miyakawa T, Kinoshita M (2007) Sept4, a component of presynaptic scaffold and Lewy bodies, is required for the suppression of alpha-synuclein neurotoxicity. Neuron 53:519 533

Iwai A (2000) Properties of NACP/alpha-synuclein and its role in Alzheimer's disease. Biochim Biophys Acta 1502:95-109

Iwai A, Yoshimoto M, Masliah E, Saitoh T (1995a) Non-A beta component of Alzheimer's disease amyloid (NAC) is amyloidogenic. Biochemistry 34:10139-10145

Iwai A, Masliah E, Yoshimoto M, Ge N, Flanagan L, de Silva HA, Kittel A, Saitoh T (1995b) The precursor protein of non-A beta component of Alzheimer's disease amyloid is a presynaptic protein of the central nervous system. Neuron 14:467-475

Iwai A, Masliah E, Sundsmo MP, DeTeresa R, Mallory M, Salmon DP, Saitoh T (1996) The synaptic protein NACP is abnormally expressed during the progression of Alzheimer's disease. Brain Res 720:230-234

Jao CC, Der-Sarkissian A, Chen J, Langen R (2004) Structure of membrane-bound alpha-synuclein studied by site-directed spin labeling. Proc Natl Acad Sci USA 101:8331-8336

Jellinger KA, Attems J (2006) Does striatal pathology distinguish Parkinson disease with dementia and dementia with Lewy bodies? Acta Neuropathol (Berl) 112:253-260

Kahle PJ, Neumann M, Ozmen L, Muller V, Odoy S, Okamoto N, Jacobsen H, Iwatsubo T, Trojanowski JQ, Takahashi H, Wakabayashi K, Bogdanovic N, Riederer P, Kretzschmar HA, Haass C (2001) Selective insolubility of alpha-synuclein in human Lewy body diseases is recapitulated in a transgenic mouse model. Am J Pathol 159:2215-2225

Kamenetz F, Tomita T, Hsieh H, Seabrook G, Borchelt D, Iwatsubo T, Sisodia S, Malinow R (2003) APP processing and synaptic function. Neuron 37:925-937

Kazlauskaite J, Pinheiro TJ (2005) Aggregation and fibrillization of prions in lipid membranes. Biochem Soc Symp 72:211-222

Kim SI, Yi JS, Ko YG (2006) Amyloid beta oligomerization is induced by brain lipid rafts. J Cell Biochem 99:878-889

Kirik D, Rosenblad C, Burger C, Lundberg C, Johansen TE, Muzyczka N, Mandel RJ, Bjorklund A (2002) Parkinson-like neurodegeneration induced by targeted overexpression of alphasynuclein in the nigrostriatal system. J Neurosci 22:2780-2791

Klein WL, Krafft GA, Finch CE (2001) Targeting small Abeta oligomers: the solution to an Alzheimer's disease conundrum? Trends Neurosci 24:219-224

Klein RL, King MA, Hamby ME, Meyer EM (2002) Dopaminergic cell loss induced by human A30P alpha-synuclein gene transfer to the rat substantia nigra. Hum Gene Ther 13:605-612

Koo EH, Squazzo SL (1994) Evidence that production and release of amyloid beta-protein involves the endocytic pathway. J Biol Chem 269:17386-17389

Kubo S, Nemani VM, Chalkley RJ, Anthony MD, Hattori N, Mizuno Y, Edwards RH, Fortin DL (2005) A combinatorial code for the interaction of alpha-synuclein with membranes. J Biol Chem 280:31664-31672

Kurata T, Kawarabayashi T, Murakami T, Miyazaki K, Morimoto N, Ohta Y, Takehisa Y, Nagai M, Ikeda M, Matsubara E, Westaway D, Hyslop PS, Harigaya Y, Kamiya T, Shoji M, Abe $\mathrm{K}$ (2007) Enhanced accumulation of phosphorylated 
alpha-synuclein in double transgenic mice expressing mutant beta-amyloid precursor protein and presenilin-1. J Neurosci Res 85:2246-2252

Lansbury PT Jr (1999) Evolution of amyloid: what normal protein folding may tell us about fibrillogenesis and disease. Proc Natl Acad Sci USA 96:3342-3344

Lashuel HA, Petre BM, Wall J, Simon M, Nowak RJ, Walz T, Lansbury PT Jr (2002) Alpha-synuclein, especially the Parkinson's disease-associated mutants, forms pore-like annular and tubular protofibrils. J Mol Biol 322:1089-1102

Lashuel HA, Hartley DM, Petre BM, Wall JS, Simon MN, Walz T, Lansbury PT Jr (2003) Mixtures of wild-type and a pathogenic (E22G) form of Abeta40 in vitro accumulate protofibrils, including amyloid pores. J Mol Biol 332:795-808

Lee M, Hyun D, Halliwell B, Jenner P (2001) Effect of the overexpression of wild-type or mutant alpha-synuclein on cell susceptibility to insult. J Neurochem 76:998-1009

Lee MK, Stirling W, Xu Y, Xu X, Qui D, Mandir AS, Dawson TM, Copeland NG, Jenkins NA, Price DL (2002) Human alphasynuclein-harboring familial Parkinson's disease-linked Ala$53 \rightarrow$ Thr mutation causes neurodegenerative disease with alpha-synuclein aggregation in transgenic mice. Proc Natl Acad Sci USA 99:8968-8973

Lee HJ, Patel S, Lee SJ (2005) Intravesicular localization and exocytosis of alpha-synuclein and its aggregates. J Neurosci 25:6016-6024

Leverenz JB, Fishel MA, Peskind ER, Montine TJ, Nochlin D, Steinbart E, Raskind MA, Schellenberg GD, Bird TD, Tsuang D (2006) Lewy body pathology in familial Alzheimer disease: evidence for disease- and mutation-specific pathologic phenotype. Arch Neurol 63:370-376

Li W, West N, Colla E, Pletnikova O, Troncoso JC, Marsh L, Dawson TM, Jakala P, Hartmann T, Price DL, Lee MK (2005) Aggregation promoting C-terminal truncation of alpha-synuclein is a normal cellular process and is enhanced by the familial Parkinson's disease-linked mutations. Proc Natl Acad Sci USA 102:2162-2167

Lin H, Bhatia R, Lal R (2001) Amyloid beta protein forms ion channels: implications for Alzheimer's disease pathophysiology. FASEB J 15:2433-2444

Lippa CF, Fujiwara H, Mann DM, Giasson B, Baba M, Schmidt ML, Nee LE, O'Connell B, Pollen DA, St George-Hyslop P, Ghetti B, Nochlin D, Bird TD, Cairns NJ, Lee VM, Iwatsubo T, Trojanowski JQ (1998) Lewy bodies contain altered alphasynuclein in brains of many familial Alzheimer's disease patients with mutations in presenilin and amyloid precursor protein genes. Am J Pathol 153:1365-1370

Lippa CF, Schmidt ML, Lee VM, Trojanowski JQ (1999) Antibodies to alpha-synuclein detect Lewy bodies in many Down's syndrome brains with Alzheimer's disease. Ann Neurol 45:353-357

Lippa SM, Lippa CF, Mori H (2005) Alpha-synuclein aggregation in pathological aging and Alzheimer's disease: the impact of betaamyloid plaque level. Am J Alzheimers Dis Other Demen 20:315-318

Lippa CF, Duda JE, Grossman M, Hurtig HI, Aarsland D, Boeve BF, Brooks DJ, Dickson DW, Dubois B, Emre M, Fahn S, Farmer JM, Galasko D, Galvin JE, Goetz CG, Growdon JH, GwinnHardy KA, Hardy J, Heutink P, Iwatsubo T, Kosaka K, Lee VM, Leverenz JB, Masliah E, McKeith IG, Nussbaum RL, Olanow CW, Ravina BM, Singleton AB, Tanner CM, Trojanowski JQ, Wszolek ZK (2007) DLB and PDD boundary issues: diagnosis, treatment, molecular pathology, and biomarkers. Neurology 68:812-819

Lo Bianco C, Ridet JL, Schneider BL, Deglon N, Aebischer P (2002) alpha-Synucleinopathy and selective dopaminergic neuron loss in a rat lentiviral-based model of Parkinson's disease. Proc Natl Acad Sci USA 99:10813-10818

Luo Y, Bolon B, Kahn S, Bennett BD, Babu-Khan S, Denis P, Fan W, Kha H, Zhang J, Gong Y, Martin L, Louis JC, Yan Q, Richards WG, Citron M, Vassar R (2001) Mice deficient in BACE1, the Alzheimer's beta-secretase, have normal phenotype and abolished beta-amyloid generation. Nat Neurosci 4:231-232

Mandal PK, Pettegrew JW, Masliah E, Hamilton RL, Mandal R (2006) Interaction between Abeta peptide and alpha synuclein: molecular mechanisms in overlapping pathology of Alzheimer's and Parkinson's in dementia with Lewy body disease. Neurochem Res 31:1153-1162

Masliah E, Terry R (1994) The role of synaptic pathology in the mechanisms of dementia in Alzheimer's disease. Clin Neurosci 1:192-198

Masliah E, Miller A, Terry RD (1993) The synaptic organization of the neocortex in Alzheimer's disease. Med Hypotheses 41: $334-340$

Masliah E, Iwai A, Mallory M, Ueda K, Saitoh T (1996a) Altered presynaptic protein NACP is associated with plaque formation and neurodegeneration in Alzheimer's disease. Am J Pathol 148:201-210

Masliah E, Sisk A, Mallory M, Mucke L, Schenk D, Games D (1996b) Comparison of neurodegenerative pathology in transgenic mice overexpressing V717F b-amyloid precursor protein and Alzheimer's disease. J Neurosci 16:5795-5811

Masliah E, Rockenstein E, Veinbergs I, Mallory M, Hashimoto M, Takeda A, Sagara Y, Sisk A, Mucke L (2000) Dopaminergic loss and inclusion body formation in alpha-synuclein mice: implications for neurodegenerative disorders. Science 287:1265-1269

Masliah E, Rockenstein E, Veinbergs I, Sagara Y, Mallory M, Hashimoto M, Mucke L (2001) Beta-amyloid peptides enhance alpha-synuclein accumulation and neuronal deficits in a transgenic mouse model linking Alzheimer's disease and Parkinson's disease. Proc Natl Acad Sci USA 98:12245-12250

Mattson MP (2007) Calcium and neurodegeneration. Aging Cell $6: 337-350$

McKeith IG (2000) Spectrum of Parkinson's disease, Parkinson's dementia, and Lewy body dementia. Neurol Clin 18:865-902

McKeith IG, Dickson DW, Lowe J, Emre M, O'Brien JT, Feldman H, Cummings J, Duda JE, Lippa C, Perry EK, Aarsland D, Arai H, Ballard CG, Boeve B, Burn DJ, Costa D, Del Ser T, Dubois B, Galasko D, Gauthier S, Goetz CG, Gomez-Tortosa E, Halliday G, Hansen LA, Hardy J, Iwatsubo T, Kalaria RN, Kaufer D, Kenny RA, Korczyn A, Kosaka K, Lee VM, Lees A, Litvan I, Londos E, Lopez OL, Minoshima S, Mizuno Y, Molina JA, Mukaetova-Ladinska EB, Pasquier F, Perry RH, Schulz JB, Trojanowski JQ, Yamada M (2005) Diagnosis and management of dementia with Lewy bodies: third report of the DLB Consortium. Neurology 65:1863-1872

Mishizen-Eberz AJ, Norris EH, Giasson BI, Hodara R, Ischiropoulos H, Lee VM, Trojanowski JQ, Lynch DR (2005) Cleavage of alpha-synuclein by calpain: potential role in degradation of fibrillized and nitrated species of alpha-synuclein. Biochemistry 44:7818-7829

Moechars D, Dewachter I, Lorent K, Reverse D, Baekelandt V, Naidu A, Tesseur I, Spittaels K, van den Haute C, Checler F, Godaux E, Cordell B, Van Leuven F (1999) Early phenotypic changes in transgenic mice that overexpress different mutants of amyloid precursor protein in brain. J Biol Chem 274:6483-6492

Moolman DL, Vitolo OV, Vonsattel JP, Shelanski ML (2004) Dendrite and dendritic spine alterations in Alzheimer models. J Neurocytol 33:377-387

Mucke L, Masliah E, Yu GQ, Mallory M, Rockenstein EM, Tatsuno G, Hu K, Kholodenko D, Johnson-Wood K, McConlogue L (2000) High-level neuronal expression of abeta 1-42 in 
wild-type human amyloid protein precursor transgenic mice: synaptotoxicity without plaque formation. J Neurosci 20:40504058

Murphy DD, Rueter SM, Trojanowski JQ, Lee VM (2000) Synucleins are developmentally expressed, and alpha-synuclein regulates the size of the presynaptic vesicular pool in primary hippocampal neurons. J Neurosci 20:3214-3220

Narhi L, Wood SJ, Steavenson S, Jiang Y, Wu GM, Anafi D, Kaufman SA, Martin F, Sitney K, Denis P, Louis JC, Wypych J, Biere AL, Citron M (1999) Both familial Parkinson's disease mutations accelerate alpha-synuclein aggregation. J Biol Chem 274:9843-9846

Nixon RA, Cataldo AM (2006) Lysosomal system pathways: genes to neurodegeneration in Alzheimer's disease. J Alzheimers Dis 9:277-289

Perry E (1995) Cholinergic signaling in Alzheimer disease: therapeutic strategies. Alzheimer Dis Assoc Disord 9(Suppl 2):1-2

Perry EK, Tomlinson BE, Blessed G, Bergmann K, Gibson PH, Perry RH (1978) Correlation of cholinergic abnormalities with senile plaques and mental test scores in senile dementia. Br Med J 2:1457-1459

Pettegrew J (1989) Molecular insights into Alzheimer's disease. In: Boller F, Katzman R, Rascol A, Signoret J-L, Christen Y (eds) Biological markers of Alzheimer's disease. Springer-Verlag, New York, pp 83-104

Pletnikova O, West N, Lee MK, Rudow GL, Skolasky RL, Dawson TM, Marsh L, Troncoso JC (2005) Abeta deposition is associated with enhanced cortical alpha-synuclein lesions in Lewy body diseases. Neurobiol Aging 26:1183-1192

Price DL, Wong PC, Markowska AL, Lee MK, Thinakaren G, Cleveland DW, Sisodia SS, Borchelt DR (2000) The value of transgenic models for the study of neurodegenerative diseases. Ann N Y Acad Sci 920:179-191

Quist A, Doudevski I, Lin H, Azimova R, Ng D, Frangione B, Kagan B, Ghiso J, Lal R (2005) Amyloid ion channels: a common structural link for protein-misfolding disease. Proc Natl Acad Sci USA 102:10427-10432

Richfield EK, Thiruchelvam MJ, Cory-Slechta DA, Wuertzer C, Gainetdinov RR, Caron MG, Di Monte DA, Federoff HJ (2002) Behavioral and neurochemical effects of wild-type and mutated human alpha-synuclein in transgenic mice. Exp Neurol 175:3548

Rochet JC, Outeiro TF, Conway KA, Ding TT, Volles MJ, Lashuel HA, Bieganski RM, Lindquist SL, Lansbury PT (2004) Interactions among alpha-synuclein, dopamine, and biomembranes: some clues for understanding neurodegeneration in Parkinson's disease. J Mol Neurosci 23:23-34

Rockenstein E, McConlogue L, Tan H, Power M, Masliah E, Mucke L (1995) Levels and alternative splicing of amyloid b protein precursor (APP) transcripts in brains of APP transgenic mice and humans with Alzheimer's disease. J Biol Chem 270:2825728267

Rockenstein E, Mallory M, Mante M, Sisk A, Masliah E (2001) Early formation of mature amyloid-b proteins deposits in a mutant APP transgenic model depends on levels of Ab1-42. J Neurosci Res 66:573-582

Rockenstein E, Mallory M, Hashimoto M, Song D, Shults CW, Lang I, Masliah E (2002) Differential neuropathological alterations in transgenic mice expressing alpha-synuclein from the plateletderived growth factor and Thy-1 promoters. J Neurosci Res 68:568-578

Rosenberg RN (2005) New presenilin 1 mutation with Alzheimer disease and Lewy bodies. Arch Neurol 62:1808

Scheff SW, DeKosky ST, Price DA (1990) Quantitative assessment of cortical synaptic density in Alzheimer's disease. Neurobiol Aging 11:29-37
Selkoe D (1990) Amyloid b-protein deposition as a seminal pathogenic event in AD: an hypothesis. Neurobiol Aging 11:299

Selkoe DJ (1994a) Alzheimer's disease: a central role for amyloid. J Neuropathol Exp Neurol 53:438-447

Selkoe DJ (1994b) Cell biology of the amyloid beta-protein precursor and the mechanism of Alzheimer's disease. Annu Rev Cell Biol 10:373-403

Selkoe DJ (1999) Translating cell biology into therapeutic advances in Alzheimer's disease. Nature 399:A23-A31

Sinha S, Anderson JP, Barbour R, Basi GS, Caccavello R, Davis D, Doan M, Dovey HF, Frigon N, Hong J, Jacobson-Croak K, Jewett N, Keim P, Knops J, Lieberburg I, Power M, Tan H, Tatsuno G, Tung J, Schenk D, Seubert P, Suomensaari SM, Wang S, Walker D, John V et al (1999) Purification and cloning of amyloid precursor protein beta-secretase from human brain. Nature 402:537-540

Sinha S, Anderson J, John V, McConlogue L, Basi G, Thorsett E, Schenk D (2000) Recent advances in the understanding of the processing of APP to beta amyloid peptide. Ann N Y Acad Sci 920:206-208

Sisodia SS, Price DL (1995) Role of the beta-amyloid protein in Alzheimer's disease. FASEB J 9:366-370

Snider BJ, Norton J, Coats MA, Chakraverty S, Hou CE, Jervis R, Lendon CL, Goate AM, McKeel DW Jr, Morris JC (2005) Novel presenilin 1 mutation (S170F) causing Alzheimer disease with Lewy bodies in the third decade of life. Arch Neurol 62:18211830

Soto C, Branes MC, Alvarez J, Inestrosa NC (1994) Structural determinants of the Alzheimer's amyloid beta-peptide. J Neurochem 63:1191-1198

Spillantini MG, Crowther RA, Jakes R, Cairns NJ, Lantos PL, Goedert M (1998) Filamentous alpha-synuclein inclusions link multiple system atrophy with Parkinson's disease and dementia with Lewy bodies. Neurosci Lett 251:205-208

Spires TL, Meyer-Luehmann M, Stern EA, McLean PJ, Skoch J, Nguyen PT, Bacskai BJ, Hyman BT (2005) Dendritic spine abnormalities in amyloid precursor protein transgenic mice demonstrated by gene transfer and intravital multiphoton microscopy. J Neurosci 25:7278-7287

Sturchler-Pierrat C, Abramowski D, Duke M, Wiederholt K, Mistl C, Rothacher S, Ledermann B, Burki K, Frey P, Paganetti P, Waridel C, Calhoun M, Jucker M, Probst A, Staufenbiel M, Sommer B (1997) Two amyloid precursor protein transgenic mouse models with Alzheimer disease-like pathology. Proc Natl Acad Sci USA 94:13287-13292

Terry RD, Masliah E, Salmon DP, Butters N, DeTeresa R, Hill R, Hansen LA, Katzman R (1991) Physical basis of cognitive alterations in Alzheimer's disease: synapse loss is the major correlate of cognitive impairment. Ann Neurol 30:572-580

Trojanowski JQ, Lee VM (2000) "Fatal attractions" of proteins. A comprehensive hypothetical mechanism underlying Alzheimer's disease and other neurodegenerative disorders. Ann N Y Acad Sci 924:62-67

Trojanowski JQ, Schmidt ML, Shin RW, Bramblett GT, Rao D, Lee VM (1993) Altered tau and neurofilament proteins in neurodegenerative diseases: diagnostic implications for Alzheimer's disease and Lewy body dementias. Brain Pathol 3:45-54

Trojanowski JQ, Goedert M, Iwatsubo T, Lee VM (1998) Fatal attractions: abnormal protein aggregation and neuron death in Parkinson's disease and Lewy body dementia. Cell Death Differ 5:832-837

Tsigelny IF, Bar-On P, Sharikov Y, Crews L, Hashimoto M, Miller MA, Keller SH, Platoshyn O, Yuan JX, Masliah E (2007) Dynamics of alpha-synuclein aggregation and inhibition of porelike oligomer development by beta-synuclein. FEBS J 274: 1862-1877 
Tsigelny IF, Crews L, Desplats P, Shaked GM, Sharikov Y, Mizuno H, Spencer B, Rockenstein E, Trejo M, Platoshyn O, Yuan JX, Masliah E (2008) Mechanisms of hybrid oligomer formation in the pathogenesis of combined Alzheimer's and Parkinson's diseases. PLoS ONE 3:e3135

Ueda K, Fukushima H, Masliah E, Xia Y, Iwai A, Yoshimoto M, Otero DA, Kondo J, Ihara Y, Saitoh T (1993) Molecular cloning of cDNA encoding an unrecognized component of amyloid in Alzheimer disease. Proc Natl Acad Sci USA 90:11282-11286

Uversky VN, Lee HJ, Li J, Fink AL, Lee SJ (2001) Stabilization of partially folded conformation during alpha-synuclein oligomerization in both purified and cytosolic preparations. J Biol Chem 276:43495-43498

Uversky VN, Li J, Souillac P, Millett IS, Doniach S, Jakes R, Goedert M, Fink AL (2002) Biophysical properties of the synucleins and their propensities to fibrillate: inhibition of alpha-synuclein assembly by beta- and gamma-synucleins. J Biol Chem 277:11970-11978

van der Putten H, Wiederhold KH, Probst A, Barbieri S, Mistl C, Danner S, Kauffmann S, Hofele K, Spooren WP, Ruegg MA, Lin S, Caroni P, Sommer B, Tolnay M, Bilbe G (2000) Neuropathology in mice expressing human alpha-synuclein. $\mathrm{J}$ Neurosci 20:6021-6029

Vassar R, Bennett BD, Babu-Khan S, Kahn S, Mendiaz EA, Denis P, Teplow DB, Ross S, Amarante P, Loeloff R, Luo Y, Fisher S, Fuller J, Edenson S, Lile J, Jarosinski MA, Biere AL, Curran E, Burgess T, Louis JC, Collins F, Treanor J, Rogers G, Citron M (1999) Beta-secretase cleavage of Alzheimer's amyloid precursor protein by the transmembrane aspartic protease BACE. Science 286:735-741

Volles MJ, Lansbury PT Jr (2002) Vesicle permeabilization by protofibrillar alpha-synuclein is sensitive to Parkinson's diseaselinked mutations and occurs by a pore-like mechanism. Biochemistry 41:4595-4602

von Coelln R, Thomas B, Andrabi SA, Lim KL, Savitt JM, Saffary R, Stirling W, Bruno K, Hess EJ, Lee MK, Dawson VL, Dawson TM (2006) Inclusion body formation and neurodegeneration are parkin independent in a mouse model of alpha-synucleinopathy. J Neurosci 26:3685-3696

Wakabayashi K, Yoshimoto M, Tsuji S, Takahashi H (1998a) Alphasynuclein immunoreactivity in glial cytoplasmic inclusions in multiple system atrophy. Neurosci Lett 249:180-182

Wakabayashi K, Hayashi S, Kakita A, Yamada M, Toyoshima Y, Yoshimoto M, Takahashi H (1998b) Accumulation of alpha-
synuclein/NACP is a cytopathological feature common to Lewy body disease and multiple system atrophy. Acta Neuropathol 96:445-452

Walsh DM, Selkoe DJ (2004) Oligomers on the brain: the emerging role of soluble protein aggregates in neurodegeneration. Protein Pept Lett 11:213-228

Williamson R, Usardi A, Hanger DP, Anderton BH (2008) Membrane-bound beta-amyloid oligomers are recruited into lipid rafts by a fyn-dependent mechanism. FASEB J 22:1552-1559

Wilson CA, Doms RW, Lee VM (1999) Intracellular APP processing and A beta production in Alzheimer disease. J Neuropathol Exp Neurol 58:787-794

Wright PE, Dyson HJ (1999) Intrinsically unstructured proteins: reassessing the protein structure-function paradigm. J Mol Biol 293:321-331

Xia Y, Rohan de Silva HA, Rosi BL, Yamaoka LH, Rimmler JB, Pericak-Vance MA, Roses AD, Chen X, Masliah E, DeTeresa R, Iwai A, Sundsmo M, Thomas RG, Hofstetter CR, Gregory E, Hansen LA, Katzman R, Thal LJ, Saitoh T (1996) Genetic studies in Alzheimer's disease with an NACP/alpha-synuclein polymorphism. Ann Neurol 40:207-215

Xia W, Ray WJ, Ostaszewski BL, Rahmati T, Kimberly WT, Wolfe MS, Zhang J, Goate AM, Selkoe DJ (2000) Presenilin complexes with the C-terminal fragments of amyloid precursor protein at the sites of amyloid beta-protein generation. Proc Natl Acad Sci USA 97:9299-9304

Xu H, Sweeney D, Wang R, Thinakaran G, Lo AC, Sisodia SS, Greengard P, Gandy S (1997) Generation of Alzheimer betaamyloid protein in the trans-Golgi network in the apparent absence of vesicle formation. Proc Natl Acad Sci USA 94:37483752

Yang F, Ueda K, Chen P, Ashe KH, Cole GM (2000) Plaqueassociated alpha-synuclein (NACP) pathology in aged transgenic mice expressing amyloid precursor protein. Brain Res 853:381383

Yoshimoto M, Iwai A, Kang D, Otero DA, Xia Y, Saitoh T (1995) $\mathrm{NACP}$, the precursor protein of the non-amyloid beta/A4 protein (A beta) component of Alzheimer disease amyloid, binds A beta and stimulates A beta aggregation. Proc Natl Acad Sci USA 92:9141-9145

Zhu M, Li J, Fink AL (2003) The association of alpha-synuclein with membranes affects bilayer structure, stability, and fibril formation. J Biol Chem 278:40186-40197 